\title{
Role of chitosan nanoparticles as anti-angiogenic in mice bearing Ehrlich carcinoma
}

\author{
Neamat H Ahmed ${ }^{1 *}$, Usama Z Said ${ }^{1}$, Nefisa H Meky ${ }^{2}$ and Manal A Mohamed ${ }^{2}$ \\ ${ }^{1}$ Radiation biology Department, National Canter for Radiation, Research and Technology, Egyptian Atomic Energy Authority, Egypt \\ ${ }^{2}$ Zoology Department, Faculty of Science, Ain Shams University, Egypt
}

\begin{abstract}
Chitosan nanoparticles (CNPs) have demonstrated anticancer activity in vitro and in vivo by a few recent researches. However, the mechanisms involved in their potential to reduce the neovascularization of tumors remain to be elucidated. In this study, the effects of CNPs on tumor neovascularization growth were investigate during a model of female mice bearing solid Ehrlich carcinoma (EC) in the neck region. After 7 days of Ehrlich ascites carcinoma cells for solid tumor induction CNPs were orally administered via gavages to mice for a period of 15 consecutive days at a dose of $0.5 \mathrm{mg} / \mathrm{kg}$ body weight. Tumor size was monitored. Oxidative stress markers were assessed and histo-pathological changes in tumor tissues were studied under light microscope. Also, Apoptotic and necrotic examination were studied under fluorescent microscope. In addition, the angiogenic markers concentrations were evaluated. In vitro, CNPs showed high antitumor activities. The results of our work showed that CNPs gavages to the experimentally EC-bearing mice, significantly reduced tumor size, increased in MDA level and decreased in GSH level in tumor tissues. Histopathologically, treatment of female mice bearing EC with CNPs recorded great destruction of tumor tissue represented by the appearance of dead and necrotic cells, underwent apoptotic cells and apoptotic zone produced a significant decrease in the levels of angiogenic markers (TNF- $\alpha$, PDGF and VEGF) which are represented as angiogenic markers. In conclusion: Chitosan nanoparticles have a role in reduce tumor growth and may represent a novel class of anti-cancer drug may represent a novel class of antiangiogenic cancer drug.
\end{abstract}

\section{Introduction}

Cancer is a serious disease where cells lose its ability to do regular cellular proliferation. Cancer ranks a second cause of mortality after the cardiovascular disease. According to world health organization (WHO). Only $5-10 \%$ of all cancer cases can be regarded to genetic defects, whereas the remaining $90-95 \%$ is regarded to the environment and lifestyle. In healthy tissues, cell differentiation, proliferation and programmed cell death (apoptosis) are closely regulated processes in maintaining organ homeostasis [1]. Tumor growth is the breakdown of these controlled processes. Tumor cells have an important qualities which are contributed to their survival, Loss of regulated cellular proliferation, loss of regulated cell differentiation, sustained cell division, evasion or inhibition of apoptosis, invasion of other tissue and organs (metastases) and angiogenesis [2]. Angiogenesis, a physiological process involving the growth of new blood vessels from pre-existing vessels, contributes to the development and progression of various pathological conditions including tumor growth and metastasis, cardiovascular diseases and inflammatory disease. Downregulation of angiogenesis has been considered to be advantageous for prevention of neoplastic growth and inflammation. Recently, anti-angiogenic strategies are based on inhibition of endothelial cell proliferation, interference with endothelial cell adhesion and migration, and interference with metalloproteinases [3]. Kobayashi and Lin [4]. Reported that tumor growth and progression depend on tumor angiogenesis, the growth of tumor blood vessels, therefore, targeting tumor angiogenesis is a very important for controlling tumor growth and/or causing regression. Nanoparticles have been shown to be delivered to specific sites by size-dependent passive targeting $[5,6]$. Chitosan, the deacetylate derivative of chitin, is one of the abundant, renewable, nontoxic and biodegradable carbohydrate polymers, and available largely in the exoskeletons of shellfish and insects. Chitosan has been widely applied as a functional biopolymer in food and pharmaceutics. Chitosan has various biological activities including immunoenhancing effects, antitumoral, antifungal, and antimicrobial activities [7-9]. The unique characteristics of chitosan nanoparticles provide a higher affinity for negatively charged biological membranes and site-specific targeting in vivo [10]. Chitosan nanoparticles could elicit dose-dependent inhibitory effects on the proliferation of various tumor cell lines, while low toxicity against normal human liver cells [11]. Our study was carried out to evaluate the anti-angiogenic efficacy of Chitosan nanoparticles on mice suffering from Ehrlich carcinoma.

\section{Material and methods}

Chemicals and reagents used in the study were of high analytical grade. Chitosan with the deacetylation degree (DD) of $>85 \%$ and the molecular weight (Mwt) of $200 \mathrm{kDa}$ was purchased from Meron (New Delhi, India). Glutaraldehyde $25 \% \mathrm{C}_{5} \mathrm{H}_{8} \mathrm{O}_{2}$ was purchased from Merck (Germany). Sodium bis (2-ethylhexyl) sulfosuccinate (AOT) $96 \%$, were purchased from Fluka (USA). Tris (hydroxymethyl)aminomethane Hydrochloride $\left(\mathrm{C}_{4} \mathrm{H}_{11} \mathrm{NO}_{3} \cdot \mathrm{HCl}\right)$ with Mwt of 121.14 was purchased from Qualikems fine chemicals Co. (New Delhi, India). Hexane 95\% was purchased from Egyptian Petroleum Research Institute EPRI

*Correspondence to: Neamat Hanafi Ahmed Osman, Radiation biology Department, National Canter for Radiation Research and Technology Egyptian Atomic Energy Authority, Cairo, Egypt, Tel: +201001731786; Email: neamatosman@yahoo.com

Key words: chitosan nanoparticles, ehrlich carcinoma, angiogenic markers

Received: April 25, 2018; Accepted: May 10, 2018; Published: May 17, 2018 
(Cairo, Egypt). Acetic acid $96 \%$ and ammonia 33\% were purchased from El Nasr pharmaceutical chemicals Co. (Cairo, Egypt). Propidium Iodide with Mwt of 668.4 was purchased from MP Biomedicals Co. (France) and Acridine Orange was purchased from LOBAL chimie Co. (France. A cell line of Ehrlich ascite carcinoma cells (EACs) was used in this study. EACs were obtained from the Egyptian National Cancer Institute (NCI), Cairo University. The tumor line was maintained in female Swiss albino mice by weekly intraperitoneal inoculation of 2.5 million cells per mouse. The EACs were counted before intraperitoneal injection using the bright line hemocytometer and dilution were made by physiological sterile saline solution and desired numbers of cells were injected in a volume of $0.2 \mathrm{ml}$. Adult female Swiss albino mice of 8 weeks old and 22-25g weight purchased from the breeding unit of the Egyptian Organization for Biological Products and Vaccines were used in this study. The animals were maintained on a commercial standard pellet diet and tap water. Animal maintenance and treatments were conducted in accordance with the National Institute of Health Guide for Animal, as approved by Institutional Animal Care and Use Committee (IACUC). Sandwich Enzyme-Linked Immunosorbent Assay (ELISA) for Quantitative Detection of Mouse TNF alpha, VEGF and PDGF concentrations in serum.

\section{Preparation of nanoparticles}

CNPs were prepared by Banerjee T et al. [12]. Briefly, dissolve the surfactant sodium bis(2-ethylhexyl) sulfosuccinate (AOT) in n-hexane. $400 \mu \mathrm{l}$ of $0.1 \% \mathrm{w} / \mathrm{v}$ chitosan solution dissolved in acetic acid was added to $40 \mathrm{ml}$ of $0.04 \mathrm{M}$ AOT solution with continuous stirring at room temperature. Evaporated the solvent off in a rotary evaporator and dry the mass in $20 \mathrm{ml}$ of Tris- $\mathrm{HCl}$ buffer ( $\mathrm{pH} \mathrm{8.0)} \mathrm{by} \mathrm{sonication.}$ Add $4 \mathrm{ml}$ of $30 \% \mathrm{CaCl}_{2}$ solution to precipitate the surfactant as calcium salt of diethyl-hexyl-sulpho-succinate. The precipitate was pelleted by centrifugation at $6000 \mathrm{rpm}$ for $15 \mathrm{~min}$ at $4{ }^{\circ} \mathrm{C}$. The cake of Ca was dissolved in $10 \mathrm{ml}$-hexane and washed two to three times with $1 \mathrm{ml}$ of Tris- $\mathrm{HCl}$ buffer. The phase-separated aqueous layer was drained out and centrifuged. Dialyzed the total aqueous dispersion of nanoparticles and lyophilized. Size and morphology of nanoparticles were done by using transmission electron microscopy (TEM). Samples for TEM were prepared using the clear solution of nanoparticles. The sample solution was put on a formvar coated grid. On this grid, a drop of the sample solution (containing dispersed nanoparticles) was placed and allowed to air-dry. A TEM picture was taken by a JOEL JEM 2000 EX200 microscope.

\section{In vitro study}

Chemosensitivity of nanoparticles (Cell viability): Antitumor effect of nanoparticles was assessed by observation of changes with respect to viable and nonviable tumor cell count. Cytotoxicity effects of the nanoparticles on tumor cells were determined according to the method of El- Merzabani et al. [13]. In order to detect the cytotoxicity of nanoparticles, EACs were treated with nanoparticles at the concentrations of $1,2,3,4,5,6,7,8,9,10,20,30,40,50,60,70,80,90$ and $100 \mu \mathrm{g} / \mathrm{ml}$. The EACs were obtained by needle aspiration of ascites fluid from the pre-inoculated mice under aseptic condition using ultra violet laminar air flow system. The percentages of non-viable cells were determined by counting dead and viable EACs. To differentiate between dead and viable EAC cells, trypan blue stain was used. Then the percentages of non-viable cells (NVC) were calculated according to the following equations $\% \mathrm{NVC}=\mathrm{C} / \mathrm{T} \mathrm{X} 100$, where $(\mathrm{C})$ is number of non-viable cells and $(\mathrm{T})$ is total number of viable cells.

\section{In vivo study}

To asses a solid mass of Ehrlich tumor, $0.2 \mathrm{ml}$ EAC cells containing $2.5 \times \mathrm{I}^{6} \mathrm{cells} / \mathrm{mouse}$ were inoculated subcutaneously in the neck region of female mouse. After 24-hour from tumor inoculation the experimental animals were subdivided into 2 groups having 10 animals in each group. T-G: Female Swiss albino mice bearing Ehrlich carcinoma and CNPs-G: Swiss albino mice bearing Ehrlich carcinoma that given chitosan nanoparticles at a dose level $0.5 \mathrm{mg} / \mathrm{kg} /$ day for 7 days.

\section{Monitoring the tumor size}

Tumor size was monitored twice or thrice weekly throughout the experiment. The tumor size being measured regularly using Vernier calipers and represented in terms of tumor size. The tumor size was estimated using the following formula: Tumor size $\left(\mathrm{mm}^{3}\right)$ $=4(\mathrm{~A} / 2)(\mathrm{B} / 2)^{2}=0.52 \mathrm{AB}^{2}$, where $\mathrm{A}$ is the major axis and $\mathrm{B}$ is the minor axis (Ghoneum et al.) [14]. The mean tumor size with the corresponding standard error was calculated in each experimental group. Two weeks ATI, experiment was terminated, and all animals were sacrificed.

\section{Sample preparation}

$15^{\text {th }}$ days ATI of final treatment of each group, experimental animals were sacrificed. Immediately Ehrlich tumor excised and rinsed in saline. Small part from tumor were placed in $10 \%$ phosphate-buffered formalin for used in histopathological and apoptotic and necrotic examinations. The rest of the Ehrlich tumor tissues were homogenates in $0.25 \mathrm{M}$ ice-cold isotonic sucrose to be used for the estimation of the biochemical assessed parameters.

\section{Histopathological examination}

A paraffin slide sections from tumor tissue was stained with Hematoxylin and eosin.

\section{Apoptosis and necrosis examination}

For apoptosis and necrosis examination according to Bank (1988) paraffin positive slides were stained in $50 \mu \mathrm{g} / \mathrm{ml}$ of propidium iodide and $50 \mu \mathrm{g} / \mathrm{ml}$ of acridine orange in phosphate-buffered saline and examined under fluorescence microscopy [15].

\section{Biochemical analysis}

All biochemical analysis was performed in Ehrlich tumor homogenate. The level of malondialdehyde (MDA), the end product of lipid peroxidation was measured according to the method of Yoshioka et al. [16]. Glutathione concentration (GSH) was determined by the method of Beulter et al. [17]. Also, serum (TNF- $\alpha$, VEGF and PDGF) were assayed by the standard sandwich enzyme-linked immune-sorbent assay (ELISA) technique using for Quantitative Detection of Mouse TNF alpha, VEGF and PDGF Concentrations in Serum.

\section{Statistical analysis}

The obtained data were expressed as mean \pm standard error (SE). All data were analyzed statistically using one-way analysis of variance (ANOVA) followed by Student's t-test. Statistical significance was considered at $\mathrm{P}<0.05$. Statistical Package for Social Sciences (SPSS) for Windows version 12.0 software was used for this analysis. 


\section{Results}

\section{Characterization of nanoparticles}

Figure 1. Represents the morphology and size of chitosan nanoparticles. TEM Observations revealed that Chitosan have a spherical shape. However, chitosan nanoparticles of cross-linking (10\%) appear as small aggregates. Ultrafine chitosan nanoparticles, as shown by the TEM images, spherical shaped uniform solid dense structure and have nearly uniform particle size distribution, which is very important for drug delivery. Average particle size of chitosan nanoparticles (CNPs) is $60 \mathrm{~nm} \pm 19 \mathrm{~nm}$ and the size for distribution ranged from 40 to $100 \mathrm{~nm}$.

\section{In vitro studies}

Chemosensitivity of nanoparticles on Ehrlich ascite carcinoma: The tumoricidal effect of different concentrations of CNPs on Ehrlich cells viability was evaluated in Table 1 and Figure 1. The low concentration $(10 \mu \mathrm{g} / \mathrm{ml})$ of CNPs decreases the tumor cells viability by $20 \%$.

The cytotoxicity of nanoparticle not only led to the death of Ehrlich carcinoma cells, but also led to burst of these dead cells at certain doses. Nanoparticles led to the rupture of cells content after their death. The median lethal concentration of CNPs was $20 \mu \mathrm{g} / \mathrm{ml}$ for Ehrlich carcinoma cells.

Table 1 and Figure 1 shows the cytotoxicity of CNPs on Ehrlich carcinoma cells. For concentration of $20 \mu \mathrm{g} / \mathrm{ml}$ Chitosan nanoparticles

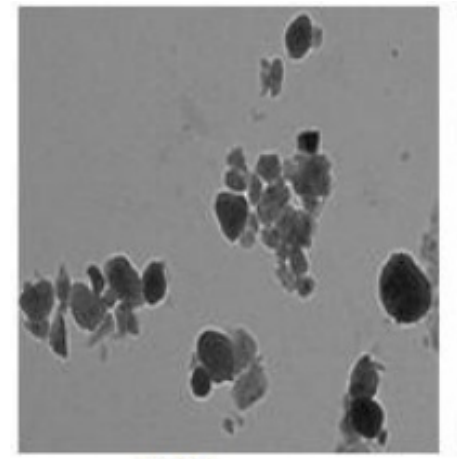

CS

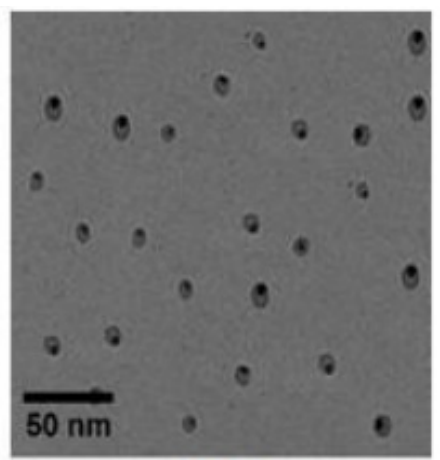

CNPS
Figure 1. Morphology and size of nanoparticles

Table 1. The effect of Chitosan nanoparticles (CNPs) on the viability of Ehrlich asciet carcinoma cells

\begin{tabular}{|c|c|c|c|}
\hline \multicolumn{4}{|c|}{ CNPs } \\
\hline $\begin{array}{c}\text { Nanoparticles } \\
\text { concentration } \\
(\boldsymbol{\mu g} / \mathbf{m L})\end{array}$ & \% of viable cells & \% of dead cells & \% of burst cells \\
\hline 0 & 99 & 1 & - \\
\hline 9 & 90 & 10 & - \\
\hline 10 & 80 & 20 & - \\
\hline 20 & 50 & 50 & 25 \\
\hline 30 & 0 & 100 & 80 \\
\hline 40 & 0 & 100 & 80 \\
\hline 50 & 0 & 100 & 95 \\
\hline 60 & 0 & 100 & 100 \\
\hline 70 & 0 & 100 & 100 \\
\hline 80 & 0 & 100 & 100 \\
\hline 90 & 0 & 100 & \\
\hline
\end{tabular}

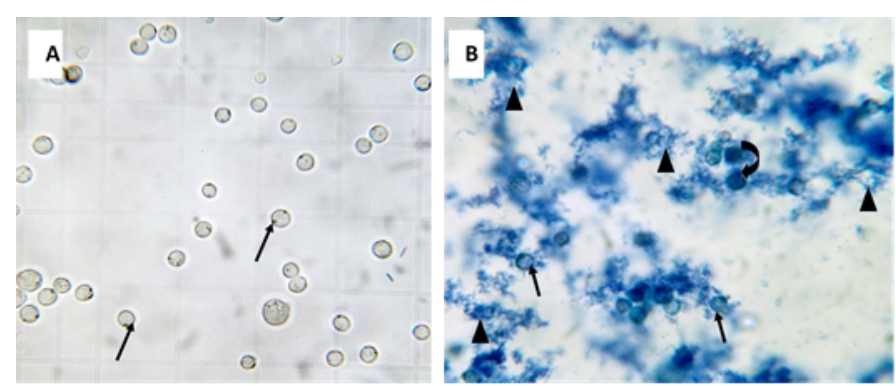

Figure 2. The effect of Chitosan nanoparticles (CNPs) on the viability of Ehrlich asciet carcinoma cells. A) Photomicrograph of Ehrlich carcinoma cells line representing $100 \%$ of viable cells ( $\uparrow)$. B) Photomicrograph of Ehrlich carcinoma cells line as affected by CNPs. Notice: underwent apoptotic ascite carcinoma cells $(\uparrow)$, rupture ascite carcinoma cells $(\boldsymbol{\Delta})$ and dead cells (curved arrow).

led to the death of $50 \%$ of Ehrlich carcinoma cells and $25 \%$ of these cells appeared to be burst. At concentration of $60 \mu \mathrm{g} / \mathrm{ml} \mathrm{CNPs}$ all Ehrlich carcinoma cells appeared to be burst (Figure 2).

Monitoring of Ehrlich carcinoma tumor size: Ehrlich tumor size is represented in Figure 3, it is clear that the inoculation of 2.5 million of Ehrlich ascites carcinoma (EAC) cells in $2 \mathrm{ml}$ physiological saline in the neck region of healthy normal mice produced a solid tumor with a mean size of $175 \pm 3.4 \mathrm{~mm}^{3}$ on the $7^{\text {th }}$ day after tumor inoculation (ATI). EC size exceeds $300 \mathrm{~mm}^{3}$ on the $9^{\text {th }}$ day ATI. The increase of EC size proceeds by days reaching $1733 \pm 19.2 \mathrm{~mm}^{3}$ on the $21^{\text {th }}$ days ATI. When mice bearing Ehrlich carcinoma gavages with $0.5 \mathrm{mg} / \mathrm{kg} /$ day CNPs for 15 days begins from the $7^{\text {th }}$ day ATI. A significant reduction in tumor size was recorded $45 \pm 5.1 \mathrm{~mm}^{3}$ on the $9^{\text {th }}$ day ATI and reaching $463 \pm 5.5 \mathrm{~mm}^{3}$ on the $21^{\text {th }}$ days ATI.

Oxidative stress markers level in different animal's groups: Tumor MDA and GSH levels are represented in Table 2. Treatment of the experimental mice-bearing EC with CNPs produced a significant increase in tumor MDA by $23.6 \%$ and significant decrease in tumor GSH by $45.5 \%$ against Ehrlich Carcinoma-bearing group.

The level of different angiogenic markers (TNF- $\alpha$, PDGF and VEGF) in different animals' groups: As shown on Table 3. The data obtained from the Ehrlich Carcinoma-bearing group, the mean value of TNF- $\alpha$ level was $177.7 \pm 5.3$, PDGF level was138.5 \pm 5.0 and VEGF level was $207.9 \pm 7.7$. Treatment of the experimental mice-bearing EC with Chitosan nanoparticles produced significant decrease in the TNF- $\alpha$ level by $-26.1 \%$, PDGF level by $-33.4 \%$ and VEGF level by $-52 \%$ against Ehrlich Carcinoma-bearing group.

\section{Histopathological examinations}

Histopathological examination of the Ehrlich carcinoma tumor under light microscope showed compactness and aggregation of the tumor tissue cells spread subcutaneously within the soft tissues in the neck region. Ehrlich carcinoma tumor showed groups of large, round and polygonal cells, with pleomorphic shapes, hyperchromatic nuclei and binucleation. Several degrees of cellular and nuclear pleomorphism were seen (Figure 4A). Treatment of female mice bearing Ehrlich carcinoma tumor by CNPs recorded great destruction of tumor tissue represented by the appearance of dead $(\operatorname{arc})$ and necrotic cells (star) (Figure 4B).

\section{Apoptotic and necrotic examination of the Ehrlich carcinoma}

Apoptotic and necrotic examination of the Ehrlich carcinoma under a fluorescent microscope was evaluated in Figure 5 Control section of Ehrlich carcinoma represents vital tissue stained in green 
stain with no zones of necrosis (orange cells) or apoptosis (yellow cells) (Figure 5A). Treatment of female mice bearing Ehrlich carcinoma 7 days ATI for 15 days with CNPs represents many zones of sporadic underwent apoptotic cells in addition to the presence of apoptotic zone (Figure 5B).

\section{Discussion}

Nanoparticles may be defined as submicronic colloidal systems that are generally composed of polymers. In recent years, nanoparticles
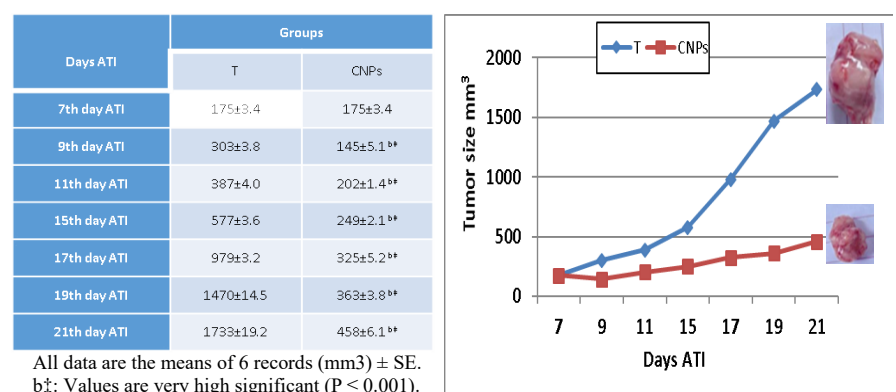

Figure 3. Effect of Chitosan-nanoparticles Ehrlich Carcinoma (EC) tumor size
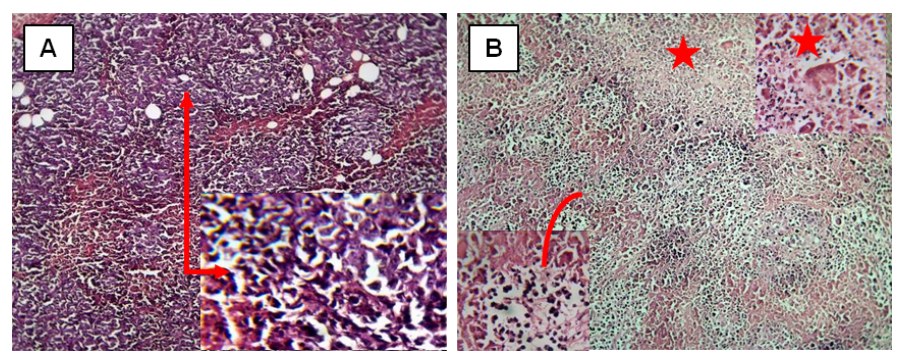

Figure 4. Photomicrograph represents control Ehrlich carcinoma in mice (A), treated by Chitosan nanoparticles (B). (H \& E x 100).

Table 2. Effect of Chitosan nanoparticles on Tumor tissue TBARS level $(\mu \mathrm{mol} / \mathrm{gm}$ wet tissue homogenate) and GSH level (mgGSH/1gm fresh tissue) of mice bearing Ehrlich carcinoma

\begin{tabular}{|c|c|c|c|}
\hline \multicolumn{1}{|r|}{ Garameter } & Mean \pm SE & $107.4 \pm 1.0$ & $132.8 \pm 1.1 \mathrm{~b}^{\ddagger}$ \\
\hline \multirow{2}{*}{ MDA } & $\begin{array}{c}\text { \% of change from } \\
\text { E.C }\end{array}$ & 0 & 23.6 \\
\hline \multirow{2}{*}{ GSH } & Mean \pm SE & $3.3 \pm 0.09$ & $1.8 \pm 0.09 \mathrm{~b}^{\ddagger}$ \\
\cline { 2 - 4 } & $\begin{array}{c}\text { \% of change from } \\
\text { E.C }\end{array}$ & 0 & -45.5 \\
\hline
\end{tabular}

Values are expressed as Means of 6 records \pm standard Error $(M \pm S E) b^{\ddagger}$ : very highly significant against $\mathrm{EC}$ at $(\mathrm{P} \leq 0.001)$.

Table 3. Effect of Chitosan nanoparticles on TNF- $\alpha$, PDGF and VEGF levels (pg/ml) of mice bearing Ehrlich carcinoma

\begin{tabular}{|c|c|c|c|}
\hline \multicolumn{1}{|c|}{ Parameter } & Groups & E.C & E. CNPs \\
\hline \multirow{2}{*}{ TNF- $\alpha$ level } & $\begin{array}{c}\text { Mean } \pm \text { SE } \\
\text { \% of change from } \\
\text { E.C }\end{array}$ & $117.7 \pm 5.3$ & $87 \pm 2.4 \mathrm{~b}^{\ddagger}$ \\
\hline \multirow{2}{*}{ PDGF level } & Mean \pm SE & $138.5 \pm 5.0$ & -26.1 \\
\cline { 2 - 4 } & $\begin{array}{c}\text { \% of change from } \\
\text { E.C }\end{array}$ & 0 & $92.2 \pm 5.1 \mathrm{~b}^{\ddagger}$ \\
\hline VEGF level & Mean \pm SE & $207.9 \pm 7.7$ & -33.4 \\
\hline & $\begin{array}{c}\text { \% of change from } \\
\text { E.C }\end{array}$ & 0 & $-59.8 \pm 11.8 \mathrm{~b}^{\ddagger}$ \\
\hline
\end{tabular}

Values are expressed as Means of 6 records \pm standard Error $(\mathrm{M} \pm \mathrm{SE}) \mathrm{b}^{\mathrm{t}}$ : very highly significant against $\mathrm{EC}$ at $(\mathrm{P} \leq 0.001)$.
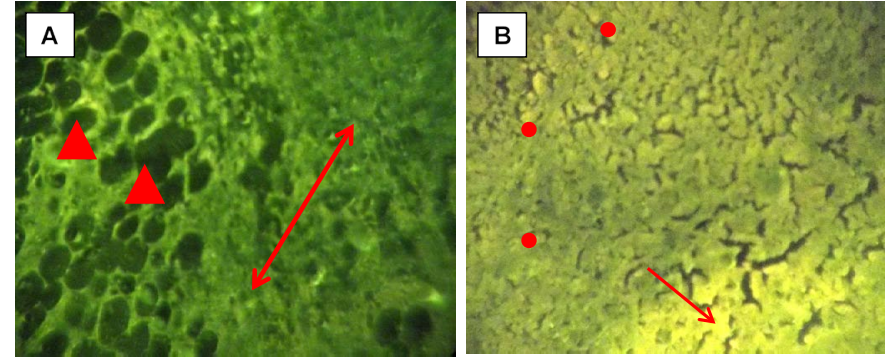

Figure 5. Fluorescent imaging of sections in Ehrlich carcinoma stained by Acridine orange / propidium iodide stain. A: Control Ehrlich carcinoma. B: Ehrlich carcinoma treated by CNPs. All magnifications x 250. Propidium iodide (dead cells, red, astric), acridine orange (living cells, green and apoptoic cells, yellow, $\uparrow$ )

have been explored with some success in maintaining or improving the anti-tumor activity of the anticancer agents. Chitosan is an interesting natural material occurring in abundance in the environment. Its excellent biocompatibility and several advantages due to its unique polymer cationic character render it highly useful for pharmaceutical application [18,19]. Chitosan nanoparticles (CNPs) have been previously synthesized as drug carriers [20-23].

In the present study the cytotoxicity of CNPs on Ehrlich carcinoma cell line was carried out. The present study demonstrated that chitosan nanoparticles could exert a high cytotoxicity against Ehrlich ascite carcinoma cell line. The median lethal concentration of CNPs was 20 $\mu \mathrm{g} / \mathrm{ml}$ and at concentration of $60 \mu \mathrm{g} / \mathrm{ml}$ CNPs all Ehrlich carcinoma cells appeared to be burst. The cytotoxicity effect of nano particles is due to their adherence to the cell membrane, particle internalization and degradation of products in the cell culture medium or inside the cells reported that due to chitosan biocompatibility and biodegradability, chitosan nanoparticles could exert a high cytotoxicity against Ehrlich ascite carcinoma cell line $[24,25]$. On the other hand, CNPs are positively charged due to the cationic characteristics of chitosan [26]. Chitosan nanoparticles could be first adsorbed onto the negatively charged tumor cell membrane by electron interaction, then exhibit antitumor effects by damaging membrane and disrupting organelle, and finally lead to cell death with the structure breakdown [11]. Another studies, found that chitosan nanoparticles are capable of changing the composition of the cell membrane of malignant cells. The investigators found that CNPs also neutralized the surface charge of human liver tumor cells and altered the charge of the membrane surrounding the cells' mitochondria [27].

Mitra et al. studied the in vivo efficacy of using chitosan nanoparticles as a drug carrier and suggest that encapsulation of the conjugate in nanoparticles not only reduces the side effects, but also improves its therapeutic efficacy in the treatment of solid tumors [28]. In the present study when experimental animal's gavage with CNPs, delay in tumor size was recorded. In the present study the increase of EC size proceeds by days reaching $1733 \pm 19.2 \mathrm{~mm}^{3}$ on the $21^{\text {th }}$ days ATI meanwhile when mice bearing Ehrlich carcinoma gavages with $0.5 \mathrm{mg} /$ $\mathrm{kg} /$ day CNPs for 15 days begins from the $7^{\text {th }}$ day ATI, $463 \pm 5.5 \mathrm{~mm}^{3}$ on the $21^{\text {th }}$ days ATI $463 \pm 5.5 \mathrm{~mm}^{3}$ on the $21^{\text {th }}$ days ATI.

The mechanism of nanoparticles in reducing the tumor size may be through the long-circulating nanoparticulate carriers. They are able to efficiently deliver the chemotherapeutics to solid tumors by exploiting the enhanced permeability and retention effect and thus can significantly enhance the therapeutic index of the drug or improve reducing undesirable side effects. Studies recorded that ultra-low size particles made of hydrogel polymer such as chitosan can efficiently 
be targeted to the tumor tissue through the combined effects of extravagation and long circulation in blood [29].

On the other hand, context with the finding of Zhang et al. [30] and consensus with the role of CNPs in tumor destruction, treatment of the experimental animals with CNPs great destruction and appearance of dead and necrotic cells represents many zones of sporadic underwent apoptotic cells in addition to the presence of apoptotic zone were detected in Ehrlich carcinoma.

There are many evidences showing that nanoparticles increase ROS production in different types of cancer cells [31-34]. In the present study treatment of experimental animals bearing Ehrlich carcinoma by CNPs recorded a significant increase in tumor MDA level compared to untreated tumor bearing group influenced by CNPs treatments. The inverse linear relationship between the ROS level and the GSH level indicated that free radical species were generated by exposure to nanoparticles which reduced intracellular antioxidant levels [35]. Treatment of experimental animals bearing Ehrlich carcinoma by CNPs developed a significant decrease in tumor GSH level compared to the level in tumor tissue of mice bearing Ehrlich carcinoma group. Furthermore, depletion cause mitochondrial dysfunction and changes in expression of distinct genes and pathways related to inflammatory responses and apoptosis including MAPK/ERK kinase, NFjB, MIP-2, caspase- 3, Bcl-2 [36-38].

The present study shows that the treatment of the experimental mice-bearing EC with CNPs produced a significant decrease in the levels of TNF- $\alpha$, PDGF and VEGF which are represented as angiogenic markers, against Ehrlich Carcinoma-bearing group.

It has been demonstrated in many in vivo studies that angiogenesis is responsible for tumour growth and metastasis. thus, inhibiting angiogenesis and tumor growth are diminished.35-38MMP-3 plays a crucial role in angiogenic switching by increasing VEGF bioavailability. PDGF and VEGF were the most potent inducer of tumor angiogenesis [39-40]. PDGF, VEGF and TNF- $\alpha$ levels were analyzed in the sera of EC bearing mice and found to be decreased $(\mathrm{p}<0.05)$ by CNPs exerting the anti-angiogenic activity. This result was fortified with the prevention of blood vessel in peritoneal lining of EC bearing Swiss albino mice. TNF- $\alpha$ was the major mediator of inflammatory response $[41,42]$.

Our study showed reduced TNF- $\alpha$ level in the sera of CNPs treated mice. The decrease in TNF- $\alpha$ levels suggests an anti-inflammatory effect which might delay cancer progression [43].

In EC bearing mice, the elevated cytokine (TNF- $\alpha$ ) level may be attributed to oxidative stress. This might have initiated the immune response and activated transcriptional factor $\mathrm{NF \kappa B}$ which in turn elevated TNF- $\alpha$ levels. Treatment with CNPs decreased the TNF- $\alpha$ increased MDA level and decreased GSH level of EC bearing mice which rejuvenated the scavenging process to remove any ROS or free radical formed during tumor progression [44].

In conclusion, CNPs have a role in targeting Ehrlich tumor cells and showed to be prospective drug for inhibiting the production of new vacuolization.

\section{References}

1. Evan GI, Vousden K H (2001) Proliferation, cell cycle and apoptosis in cancer. Nature 411(6835): 342-348. [Crossref]

2. Hanahan D, Weinberg RA (2000) The hallmarks of cancer. Cell 100: 57-70. [Crossref]

3. Griffioen W, Molema G (2000) Angiogenesis: Potentials for pharmacologic intervention in the treatment of cancer, cardiovascular diseases, and chronic inflammation. Pharmacol Rev 52: 237-268. [Crossref]
4. Kobayashi H, Lin PC (2006) Antiangiogenic and radiotherapy for cancer treatment. Histol. Histopathol 21: 1125-1134. [Crossref]

5. Alvarez-Lorenzo C, Sosnik A, Concheiro A (2011) PEO-PPO block copolymers for passive micellar targeting and overcoming multidrug resistance in cancer therapy. $\mathrm{Curr}$ Drug Targets 12: 1112-1130. [Crossref]

6. Danhier F, Feron O, Preat V (2010) To exploit the tumor microenvironment: Passive and active tumor targeting of nanocarriers for anti-cancer drug delivery. $J$ Control Release 148: 135-146. [Crossref]

7. Qin C, Du Y, Xiao L, Li Z, Gao X (2002) Enzymic preparation of water-soluble chitosan and their antitumor activity. Int J Biol Macromol 31: 111-117. [Crossref]

8. Roller S, Covill N (1999) The antifungal properties of chitosan in laboratory media and apple juice. Int J Food Microbiol 47: 67-77. [Crossref]

9. Zheng LY, Zhu ZF (2003) Study on antimicrobial activity of chitosan with different molecular weights. Carbohyd Polym 54: 527-530.

10. Qi L, Xu Z, Jiang X, Hu C, Zou X (2004) Preparation and antibacterial activity of chitosan nanoparticles. Carbohydr Res 339: 2693-2700. [Crossref]

11. Qi L, Xu Z, Jiang X, Li Y, Wang M (2005) Cytotoxic activities of chitosan nanoparticles and copper-loaded nanoparticles. Bioorg Med Chem Lett 15: 1397-1399.

12. AK, Sharma RK, Maitra AN (2002) Preparation characterization and biodistribution of ultrafine chitosan nanoparticles. Int J Pharm 243: 93-105. [Crossref]

13. El-Merzabani MM, El-Aaser AA, Attia MA, El-Duweini AK, Ghazal AM (1979) Screening system for Egyptian plants with potential anti-tumour activity. Planta Med 36: 150-155. [Crossref]

14. Ghoneum M, Badr El-Din NK, Noaman E, Tolentino L (2008) Saccharomyces cerevisiae, the Baker's Yeast, suppresses the growth of Ehrlich carcinoma-bearing mice. Cancer Immunol Immunother 57: 581-592. [Crossref]

15. Bank HL (1988) Rapid assessment of islet viability with acridine orange and propidium iodide. In Vitro Cellular Dev Biol 4: 266-273. [Crossref]

16. Yoshioka T, Kawada K, Shimada T, Movi M (1979) Lipid per oxidation in maternal and cord blood and protective mechanism against activated oxygen toxicity in the blood. Am J Obstet Gynecol 135: 372-376. [Crossref]

17. Beulter E, Duron O, Kelly BM (1963) Improved method for the determination of blood glutathione. J Lab Clin Med 61: 882-888. [Crossref]

18. Thanoo BC, Sunny MC, Jayakrishnan A (1992) Cross-linked chitosan microspheres: preparation and evaluation as a matrix for the controlled release of pharmaceuticals. $J$ Pharm Pharmacol 44: 283-286. [Crossref]

19. Illum L (1998) Chitosan and its use as a pharmaceutical excipient. Pharm Res 15 1326-1331. [Crossref]

20. Janes KA, Fresneau MP, Marazuela A, Fabra A, Alonso MJ (2001) Chitosan nanoparticles as delivery systems for doxorubicin. J Control Rel 73: 255-267. [Crossref]

21. Pan Y, Li YJ, Zhao HY, Zheng JM, Xu H, et. al (2002) Bio adhesive polysaccharide in protein delivery system: chitosan nanoparticles improve the intestinal absorption of insulin in vivo. Int J Pharm 249: 139-147. [Crossref]

22. Xu Y, Du Y (2003) Effect of molecular structure of chitosan on protein delivery properties of chitosan nanoparticles. Int J Pharm 250: 215-226. [Crossref]

23. Poovi G, Dhana lekshmi UM, Narayanan N, Neelakanta Reddy P (2011) Preparation and characterization of repaglinide loaded chitosan polymeric nano particles. Res $J$ Nanosci Nanotechnol 1: 12- 24.

24. Abbasalipourkabir R, Salehzadeh A, Abdullah R (2011) Cytotoxicity Effect of Solid Lipid Nanoparticles on Human Breast Cancer Cell Lines. Biotechnology 10: 528-533.

25. Mi FL, Tan YC, Liang HF, Sung HW (2002) In vivo biocompatibility and degradability of a novel injectable-chitosan-based implant. Biomaterials 23: 181-191. [Crossref]

26. Hu Y, Jiang X, Ding Y, Ge H, Yuan Y, et. al (2002) Synthesis and characterization of chitosan-poly (acrylic acid) nanoparticles. Biomaterials 23: 3193-3201. [Crossref]

27. Qi L, Xu Z, Chen M, (2007) In vitro and in vivo suppression of hepatocellular carcinoma growth by chitosan nanoparticles. Eur J Cancer 43: 184-193. [Crossref]

28. Mitra S, Gaur U, Ghosh PC, Maitr AN (2001) Tumour targeted delivery of encapsulated dextran-doxorubicin conjugate using chitosan nanoparticles as carrier. $J$ Control Release 74: 317-323. [Crossref]

29. Bisht S, Maitra A (2009) Dextran-doxorubicin/chitosan nanoparticles for solid tumor therapy. Wiley Interdiscip Rev Nanomed Nanobiotechnol 1: 415-425. [Crossref] 
30. Zhang DY, Shen XZ, Wang JY, Dong L, Zheng YL, et al. (2008) Preparation of chitosan-poly aspartic acid-5 fluorouracil nanoparticles and its anti-carcinoma effect on tumor growth in nude mice. World J Gastroenterol 14: 3554-3562. [Crossref]

31. Becker S, Soukup JM, Gallagher JE (2002) Differential particulate air pollution induced oxidant stress in human granulocytes, monocytes and alveolar macrophages. Toxicol In Vitro 16: 209-218. [Crossref]

32. Peters K, Unger RE, Gatti AM, Sabbioni E, Tsaryk R, et. al (2007) Metallic nanoparticles exhibit paradoxical effects on oxidative stress and proinflammatory response in endothelial cells in vitro. Int J Immunopathol Pharmacol 20: 685-695. [Crossref]

33. Pulskamp K, Diabate S, Krug HF (2007) Carbon nanotubes show no sign of acute toxicity but induce intracellular reactive oxygen species in dependence on contaminants. Toxicol Lett 168: 58-74. [Crossref]

34. Park EJ, Choi J, Park YK, Park K (2008) Oxidative stress induced by cerium oxide nanoparticles in cultured BEAS-2B cells. Toxicology 245: 90-100. [Crossref]

35. Wang F, Gao F, Lan M, Yuan H, Huang Y, et.al (2009) Oxidative stress contributes to silica nanoparticle-induced cytotoxicity in human embryonic kidney cells. Toxicol In Vitro 23: 808-815. [Crossref]

36. Driscoll KE (2000) TNF alpha and MIP-2: role in particle-induced inflammation and regulation by oxidative stress. Toxicol Lett 112-113: 177-184. [Crossref]

37. Fubini B, Hubbard A (2003) Reactive oxygen species and reactive nitrogen species generation by silica in inflammation and fibrosis. Free Radic Biol Med 34: 1507-1516. [Crossref]
38. Kharasch ED, Schroeder JL, Bammler T, Beyer R, Srinouanprachanh S (2006) Gene expression profiling of nephrotoxicity from the sevoflurane degradation product fluoromethyl- 2,2difluoro1 (trifluoromethyl)vinyl ether ("compound A") in rats. Toxicol Sci 90: 419-431. [Crossref]

39. Matrix metalloproteinases: regulators of the tumor microenvironment. Cell 141: 52-67. [Crossref]

40. Deryugina EI, Quigley JP (2010) Pleiotropic roles of matrix metalloproteinases in tumor angiogenesis: contrasting, overlapping and compensatory functions. Biochim Biophys Acta 1803: 103-120. [Crossref]

41. Feghali CA, Wright TM (1997) Cytokines in acute and chronic inflammation. Front Biosci 2: d12-d26. [Crossref]

42. Nasti A, Zaki NM, de Leonardis P, Ungphaiboon S, Sansongsak P, et. al (2009) Chitosan/TPP and chitosan/TPP-hyaluronic acid nanoparticles: systematic optimisation of the preparative process and preliminary biological evaluation. Pharm Res 26: 19181930. [Crossref]

43. Agrawal SS, Saraswati S, Mathur R, Pandey M (2011) Cytotoxic and antitumor effects of brucineon Ehrlich ascites tumour and human cancer cell line. Life Sci 89: 147-158. [Crossref]

44. Jin H, Pi J, Yang F, Wu C, Cheng X, et. al (2016) Ursolic acid-loaded chitosan nanoparticles induce potent anti-angiogenesis in tumor. Appl Microbiol Biotechnol 100: 6643-6652. [Crossref]

Copyright: (2018 Ahmed NH. This is an open-access article distributed under the terms of the Creative Commons Attribution License, which permits unrestricted use, distribution, and reproduction in any medium, provided the original author and source are credited. 